\title{
CORRIGENDUM
}

DOI: $10.3892 / \mathrm{ol} .2018 .9790$

\section{miR-23b suppresses lung carcinoma cell proliferation through CCNG1}

HONGSHENG HAN, ZHENXIAN ZHANG, XUEQIN YANG, WENFENG YANG, CHENGWEI XUE and XIAOLI CAO

Oncol Lett 16: 4317-4324, 2018; DOI: 10.3892/ol.2018.9181

Following the publication of this article, the corresponding author, Dr Xiaoli Cao, has realized that their current affiliation, "The Affiliated Hospital of Yan'an University", should have been referenced as a "Present address" in the manuscript. Dr Cao moved in July 2018, and also received advice and guidance on the paper from The Affiliated Hospital of Yan'an University during the revision process. All the other authors on the paper agree to the inclusion of this new affilation.

Therefore, the authors' names and affiliations should have appeared in the paper as follows:

HONGSHENG HAN ${ }^{1 *}$, ZHENXIAN ZHANG ${ }^{*}$, XUEQIN $\mathrm{YANG}^{2}$, WENFENG $\mathrm{YANG}^{1}$, CHENGWEI XUE ${ }^{1}$ and XIAOLI CAO ${ }^{1,2}$

${ }^{1}$ Department of Radiology, People's Hospital of Yan'an, Yan'an; ${ }^{2}$ Department of Radiology, The Affiliated Hospital of Yan'an University, Yan'an, Shaanxi 716000, P.R. China

Correspondence to: Dr Xiaoli Cao, at the Present address: ${ }^{2}$ Department of Radiology, The Affiliated Hospital of Yan'an University, 43 North Street, Baota, Yan'an, Shaanxi 716000, P.R. China

${ }^{*}$ Contributed equally 